\title{
GENEALOGY OF HEARTH IN NUSANTARA HOUSE
}

\author{
Pancawati Dewi $^{\mathbf{1}^{*}}$, Minarni Nur Trilita ${ }^{2}$, Muchlisiniyati Safeyah ${ }^{3}$ \\ ${ }^{1}$ Architecture Department, Gunadarma University, Jl. Margonda Raya No. 100 Pondok Cina, Depok \\ ${ }^{2}$ Civil Department, UPN "Veteran" Jawa Timur, Jl. Raya Rungkut Madya Gunung Anyar Surabaya \\ ${ }^{3}$ Architecture Department, UPN "Veteran” Jawa Timur, Jl. Raya Rungkut Madya Gunung Anyar, Surabaya \\ *Corresponding author; Email: pancawati_dewi@staff.gunadarma.ac.id or dhehas@gmail.com
}

\begin{abstract}
The use of hearth in Nusantara (especially in Indonesia) all this time shows a remarkable diversity. An important role is also shown through the location and activities around it. Genealogy of hearth in Nusantara can show the evolution occurred in the use of hearth. Through the typology approach and interpretive-historical method, genealogy can be arranged based on the form or shape, function, characteristics and location of the hearth in the house in Nusantara. Genealogy of hearth in Nusantara shows the sustainability efforts from society in Indonesia in adapting and making innovations to the changing times. Technology is used wisely without having to leave the tradition that formed the life pattern of society in Nusantara.
\end{abstract}

Keywords: Hearth; shape; function; characteristic; location.

\section{INTRODUCTION}

Fireplace or hearth as the source of heat and the cooking utensil has been known as the beginning of architecture (Weston, 2011). The importance of fire in the daily life since a long time ago influenced the history of human civilization and culture. After the discovery of fire, people began to recognize the space. Fire made human beings in groups or gathered around, it had a clear and firm concentric orientation (which in the next period allowed the pattern of organized communities). Fire eventually triggered the formation of space, and it grew more complex until now (Viruvius, the Morgan 1960; Crowe, 1997; Unwin, 1997; Dewi, 2013; Dewi \& Darjosanjoto, 2011 and Dewi \& Arfianti, 2015). In the real form, hearth was created and the location was more and more permanent, and it had grown extensively into the hearth space (some used it as a place to warm themselves, cook, socialize, and as rituals). Therefore, it was not only as the hearth space, especially when space became more complex and evolved into many spaces, so that the role of fire became more important.

As presented by Pangarsa (2006), Nusantara Architecture is very broad, covering the area of sociocultural from the West to the East, from the mainland of Southeast Asia, Aceh to the East Papua islands; from north to south, from the Japan islands to the Rote islands. Indonesia itself has a large range of area which demonstrates the rich diversity of architecture in terms of shape, layout, ornament and meaning. The hearth is also very diverse in Indonesian house. This diversity is influenced not only by the topography and local climate but also strongly influenced by the socio-cultural conditions of the community (Dewi, Budiyanto, Safeyah \& Hasan, 2016).

Through the theory of hearth evolution, the hearth diversity in Indonesia can be compiled into a genealogy which explains of how and why the modification of hearth occured. The genealogy of hearth in Nusantara can also be used to understand the linkages between the hearth and the space formed. This also will be able to enrich the knowledge of space (architecture), which its linkages with hearth is still rarely investigated.

\section{EVOLUTION OF THE HEARTH}

Talking about the genealogy of the hearth in the tradition of human life, Koolhaas et al (2014) stated:

"From the caveman to the toaster, the fireplaceis the catalyst of cultural evolution. Throughout history, its various functions branch off into discrete devices, so that the fireplace, which we thought had disappeared, proves remarkably persistent and versatile in its multiple offshoots, even those that reach back into a more primitive history...."

The development of a hearth is also explained by Unwin (1997) about the evolution occured in the hearth. Changes which occured include the hearth shape, the location, and the function affected by the development of human civilization. As for the hearth shape, Unwin (1997) described a variety of methods used to make the hearth, among others: a fire can be framed in various ways: the circle of scorched earth may be contained with a circle of stones; the fire 
might be set against a large stone which protects it from excessive draught and stores some of its heat; flanked by two parallel walls of stone that channel draughts and provide a platform for cooking; provided with a tripod from which a cooking pot is hung; set in a more sophisticated construction like a seat or table until provided with its own small building.

For the hearth location, both Unwin (1997) and Koolhaas et al (2014) explained that the hearth as a focal point of dwelling placed in the middle of the room is untenable in the present condition. The hearth location began to shift from the middle of the room to the edge. The functions of the hearth also began to change. Some functions of the hearth has been replaced by technology (lights and stove), while the hearth as a medium for socializing or storytelling has been replaced by a radio or television.

According to Koolhaas et al (2014), many hearths are missing nowadays, especially in the West, but it is still found in Africa and most of Asia. Koolhaas also stated:

The fireplace's functions began to diverge from the $19^{\text {th }}$ century, taken over by individual, nonarchitectural technologies. Cooking was taken care of by the metal stove; heating became flameless, automated, relegated to a basement boiler and carried by pipes and radiators; lighting was taken care of by the bulb or strip; media and storytelling by the radio, the television, now the computer. Scattered around the house, we now each have a personal fireplace that warms our laps, at best, or more likely radiates the palms of our hands.

Dewi, Budiyanto, Safeyah \& Hasan (2016) described the hearth in Indonesia has a very important role in the sustainability of architecture, especially in dwelling house. The diversity in shape, number, position and function of the hearth is influenced by socio-cultural society. Those diversities will then be used to build knowledge about Indonesian hearth genealogy which is expected to provide an explanation of the origin of the hearth in Indonesia and how hearth can deal with the constantly changing human needs.

\section{METHODOLOGY}

Typology studies can be used to learn about the "general similarities" or "generalizations" existed in the buildings, so that people will be able to identify a building when they have recognized the typology, consciously or unconsciously (based on the memories). In this paper, the typology is applied to see the hearth used by Nusantara society, from its shape, number, location, to the changes during this time.

The immensity of Nusantara and the ethnic diversity makes typology approach is very important to get an overview of the use of hearth in Nusantara. Meanwhile, through the change or the evolution of the use of hearth which occurred during this time can be used to develop the knowledge of genealogy of the Nusantara hearth. In addition, the preparation of genealogy is also supported by interpretive-historical research method by Groat and Wang (2002). Interpretive-historical research method can be used in particular in the fireplace or hearth that has experienced a change in certain society. Historical data and interviews with selected speakers can help researchers to understand the change of use and shape of hearth. This method is done by searching for evidence, collecting and organizing the evidence, evaluating it, and constructing a narrative from the evidence that is holistic and believable. Throughout the process, interpretation is the key.

\section{RESULTS AND DISCUSSION}

\section{The Shape, Function, and Characters of Hearth}

As described by Unwin (1997) and shown by Dewi, Budiyanto, Safeyah \& Hasan (2016) about the diversity of the hearth, which started from the pile of wood to the form a hearth that resembles a table. The shape of hearth which uses woods can be placed on the top of soil excavation (Dani house in Wamena) or on a pile of rocks (Yali house and Asmat house in Papua). The next development is an effort to protect the flame from the wind, this is done by placing natural stones on one side or several sides, where the natural stones are often used to place cooking appliances. The shape of hearth consists of a series of natural stones which can still be used by Batak Karo, Sasak in Segenter and Matabesi in NTT.

The next developments, the shape of hearth has used the technology adapted to the conditions and era. The shape of hearth currently found most in Indonesia is the hearth with table form with a variety of shapes, sizes, materials and number of holes for cooking. From the table form with two or three top holes, the use of clay and brick as its material, to the brick covered with ceramics. The hearth with table form can be found in Toraja, Kampung Naga, Bali, and Tengger.

As presented by Dewi (2016) about the evolution of the use of the hearth, at first humans only use stones or piles of stones to protect the flame from being extinguished. Good stones are chosen to be 
used as a holder for cooking. While Unwin (1997) describes the evolution of hearth can be influenced by technology. Thus, nowadays hearth resembles the shape of a table. The development of hearth shape in Nusantara house can finally be illustrated in Figure 1, the first generation is the hearth which uses wood as its fuel and is placed on the floor or ground; the second generation is the hearth which uses natural stone as a place for cooking; the third generation is the hearth which shape resembles a table (figure 1).

As explained before (Dewi and Arfianti, 2015), it can be seen from Tengger case that hearth is currently experiencing segmentation by function. A multi function hearth (a multi function pawon) is still used in the kitchen (dhapur) while mono function hearth (mono function pawon) is also found in the living room (pedhayohan). The changes of hearth function is followed by the number of hearth in the house. The discovery of Dewi and Arfianti (2015) confirmed that in multi function hearth in Tengger, they always uses 1 hearth and the hearth to welcome guests can be more than one, depends on the socioeconomic of its users. The changes of the function starts to be found in other areas in Nusantara and is usually followed by the addition of the hearth. The addition of hearth is not only connected to the function but also to the shape. The addition of a hearth in the house is not only to keep warm such as the case in Tengger, but also to cook such as the cases Tenganan in Bali and Sasak in Lombok. Evolution of the use of hearth based on its function can be described as follows (figure 2).

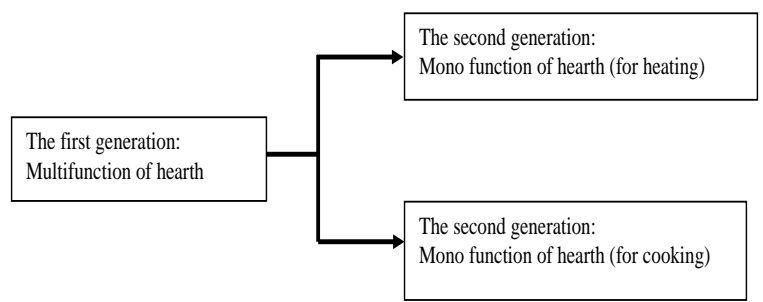

Fig. 2. Evolution of the Hearth Function in Nusantara House
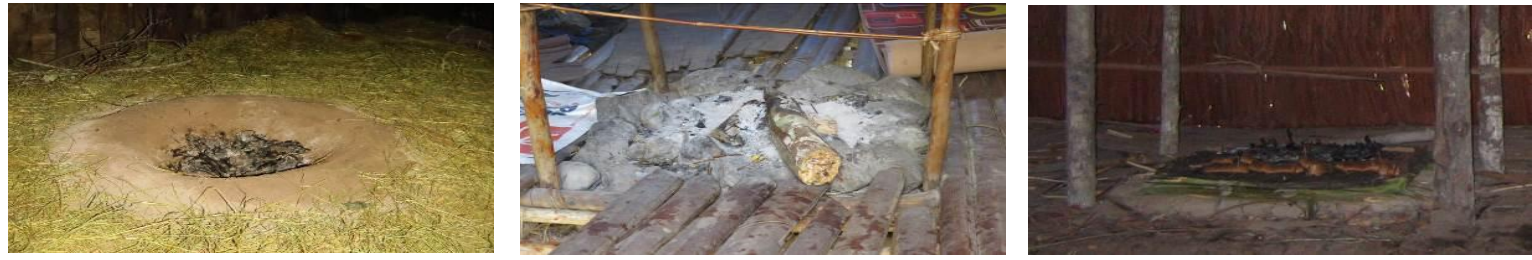

The first generation : Honai house (left); Yali house (middle) and Asmat house (right)

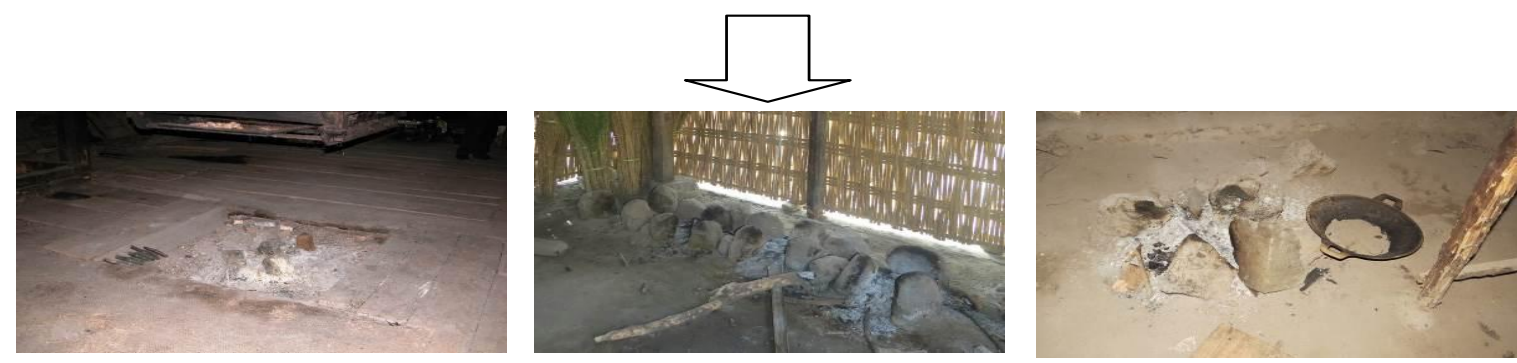

The second generation : The shape of hearth using natural stone in Batak Karo house (left); Sasak house in Segenter (middle) and Matabesi house (right)

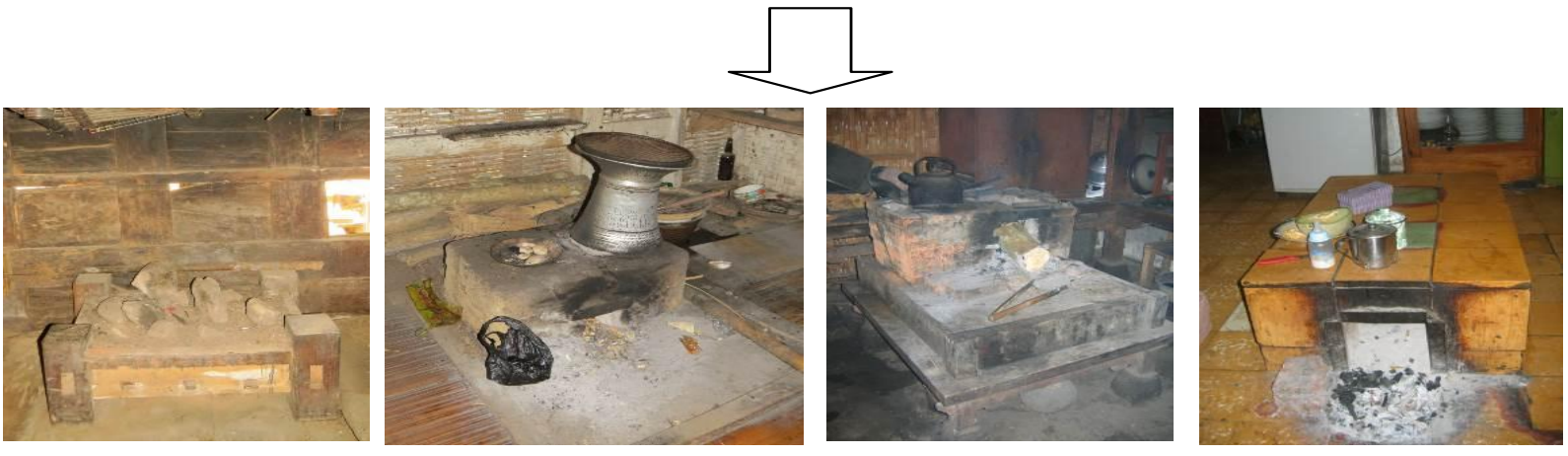

The third generation : Table-shaped hearth from left to right in Toraja house, Kampung Naga house, Bali house in Panglipuran and Tengger house

Fig. 1. Evolution of the Hearth Shape in Nusantara House 
Beside the shape and function of the hearth, the addition of the hearth in some houses in Nusantara also indicates a change in the nature of the hearth. The former hearth tends to be fixed (attached to the ground and the location is fixed or can not be moved). Whereas the addition of a new hearth in the house can be permanent and moveable with various mono functions. The addition of a new hearth can be found in Bajo tribe. As shown in Bajo tribe, there is a need of a hearth for cooking which can be brought into their boat while sailing. There is also a new addition of a hearth for cooking in Sasak tribe. In highlands Tengger tribe, the addition of a new hearth is to keep warm, with the same shape as the former hearth or in a modern one (figure 3 ).
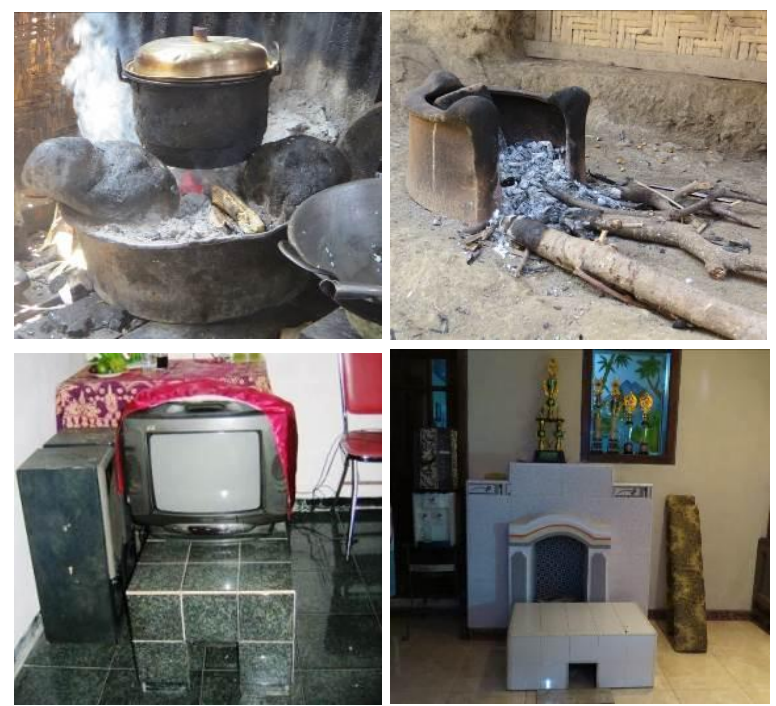

Fig. 3. Moveable Hearth from left to right: Bajo House, Sasak House, Tengger House (old and new shape)

Based on the characteristics or nature, the evolution of the hearth can be seen in figure 4, the development of a permanent hearth became moveable hearth. This development allegedly will continue to occur as a result of technological developments and the new needs that may be affected by changes in the economic and social culture of the local community.

\begin{tabular}{|l|l|}
\hline $\begin{array}{l}\text { The first generation : } \\
\text { Fix or permanent hearth }\end{array}$ & $\begin{array}{l}\text { The second generation : } \\
\text { Moveable hearth }\end{array}$ \\
\hline
\end{tabular}

Fig. 4. Evolution of the Hearth Characters in Nusantara House

\section{The Location of the Hearth}

As the center of activity in the house, it is more suitable to locate hearth in the middle of the room. Some circular houses consist of a multifunctional room with a hearth at its center are still commonly found in Nusantara, in example the house of Yali tribe (figure 5) or a square house with a hearth at its center (Tengger house in Figure 6).

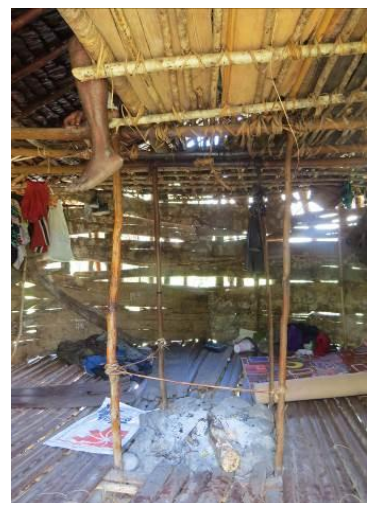

Fig. 5. The location of hearth in the Middle of Yali House

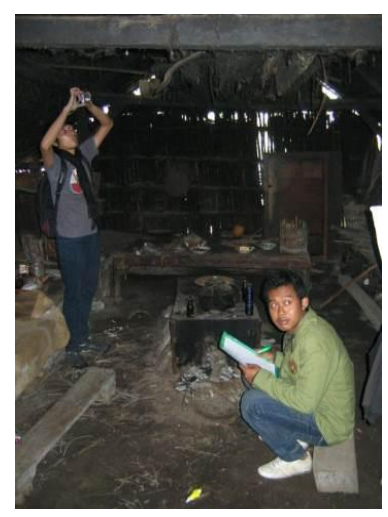

Fig. 6. The location of Hearth in the Middle of Tengger House
As described by Unwin (1997) and Koolhaas et al (2014), the transition of the location from the center of the room to the side is shown in most of the cases in Nusantara. The shifting of the hearth location is also occured in a house with a multi-function room. The change of hearth location to the side of the room is shown by maintaining the circle or square-shaped plan. The shifting the hearth location can be to the back corner of the room (Sasak house in Segenter) or to the middle part of the back wall so it is clearly visible from the entrance (Bali house in Pengotan). In addition, many hearth locations are shifted to the front near the entrance of the house as shown in Bali house in Sidatapa (figure 7).
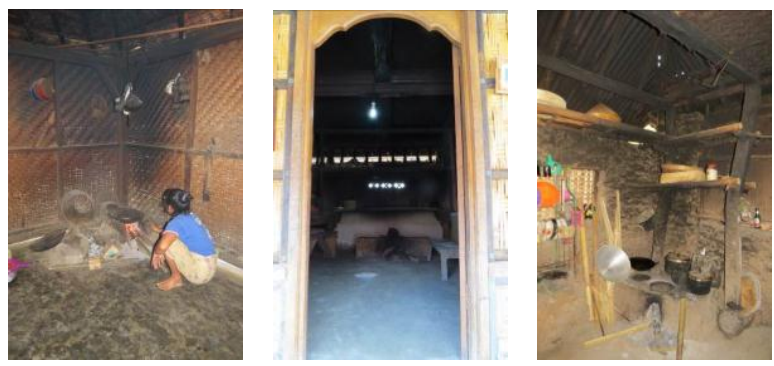

Fig. 7. The location of Hearth in the side of the Room, from left to right: Sasak House in Segenter, Bali House in Pengotan, Kampung Naga and Bali house in Sidatapa.

Besides the shifting location, the house with many rooms usually locates the hearth in a room used for cooking and other activities (= the kitchen or living room). The kitchen or living room location is diverse. Some are located on the side of the house or most tend to be located at the back house. The segmentation occured in most houses today, as is also 
to adapt to the changes in human developing needs. The emergence of new needs affected by the growing number of family members, the technology developments, and the increasing economic family, may trigger a change in the use of hearth in a house. The change of use of the hearth in Nusantara without eliminating the presence of the hearth showed the sustainability effort is maintained. Sustainability is shown by the use of new technology in some cases in Nusantara (electricity and stove) without eliminating the existence of the old hearth.

\section{REFERENCES}

Crowe, N. (1997). Nature and the Idea of A Manmade World. The MIT Press, Cambridge, Masschusetts.

Dewi, P. (2013). Fire as A Creator of Space. Conference Proceedings: Politics in the History of Architecture as Cause \& Consequence.". Mimar Fine Arts University, Istanbul, Turkey, 24-27 April 2013, pp.155-163.

Dewi, P. \& Darjosanjoto, E. (2011). The Use of Hearth in Tengger Society of East Java. International Journal of Academic Research, 3(2), pp.108-114, Baku, Azerbaijan.
Dewi, P., Budiyanto H. \& Safeyah M. (2015). Hearth as The Most Dynamic in the Sasak House. International Joint Conference SENVAR-iNTAAVAN 2015 Proceedings, Faculty of Built Environment UTM Johor Malaysia, 24-26 November 2015, pp.5-1.

Dewi, P., Budiyanto H., Safeyah M. \& Hasan, R. (2016). The Concept of Hearth to Legitimize Nusantara Architecture in Indonesia. Traditional Dwellings and Settlements Working Paper Series Titles 2016-2017 Vol. 278. IASTE University of California, Berkeley USA.

Dewi, P. (2016). Peran Perapian dalam Ruang Arsitektur, Buku Ajar, UPNV Jatim, Indonesia.

Groat L. \& Wang D. (2002). Research Methods. Canada John Wiley \& Sons Inc.

Koolhaas et al. (2014). Fireplace. Italy la Biennale di Venezia/Rem Koolhaas.

Pangarsa, G.W. (2006). Merah Putih Arsitektur Nusantara. Yogyakarta Andi Offset.

Unwin, S. (1997). Analysing Architecture. Routledge, London.

Vitruvius, M. H. M. (trans.) (1960). The Ten Books on Architecture. Dover Publications Inc, New York.

Weston, R. (2011). 100 Ideas That Changed Architecture, Laurence King Publising Ltd, London. 